\title{
"A second chance to serve South African private banking consumers: the role of post-transgression forgiveness"
}

\begin{tabular}{|c|c|}
\hline AUTHORS & Nobukhosi Dlodlo \\
\hline ARTICLE INFO & $\begin{array}{l}\text { Nobukhosi Dlodlo (2017). A second chance to serve South African private } \\
\text { banking consumers: the role of post-transgression forgiveness. Banks and Bank } \\
\text { Systems, } 12(3), 166-178 \text {. doi:10.21511/bbs.12(3-1).2017.02 }\end{array}$ \\
\hline DOI & http://dx.doi.org/10.21511/bbs.12(3-1).2017.02 \\
\hline RELEASED ON & Wednesday, 04 October 2017 \\
\hline RECEIVED ON & Tuesday, 16 May 2017 \\
\hline ACCEPTED ON & Friday, 11 August 2017 \\
\hline LICENSE & $\begin{array}{l}(c) \text { EY-NC } \\
\text { This work is licensed under a Creative Commons Attribution-NonCommercial } 4.0 \\
\text { International License }\end{array}$ \\
\hline JOURNAL & "Banks and Bank Systems" \\
\hline ISSN PRINT & $1816-7403$ \\
\hline ISSN ONLINE & $1991-7074$ \\
\hline PUBLISHER & LLC "Consulting Publishing Company "Business Perspectives" \\
\hline FOUNDER & LLC "Consulting Publishing Company "Business Perspectives" \\
\hline
\end{tabular}

NUMBER OF REFERENCES

57
NUMBER OF FIGURES

1
NUMBER OF TABLES

3

(C) The author(s) 2023. This publication is an open access article. 


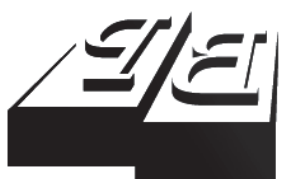

BUSINESS PERSPECTIVES

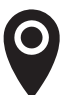

LLC "CPC "Business Perspectives" Hryhorii Skovoroda lane, 10, Sumy, 40022, Ukraine

www.businessperspectives.org

Received on: $16^{\text {th }}$ of May, 2017

Accepted on: $11^{\text {th }}$ of August, 2017

(C) Nobukhosi Dlodlo, 2017

Nobukhosi Dlodlo, Ph.D., Department of Marketing Management, Faculty of Management Sciences, Vaal University of Technology, South Africa.

\section{(ㄷ)(1) $(9$}

This is an Open Access article, distributed under the terms of the Creative Commons Attribution-NonCommercial 4.0 International license, which permits re-use, distribution, and reproduction, provided the materials aren't used for commercial purposes and the original work is properly cited.

\section{A SECOND CHANCE TO SERVE SOUTH AFRICAN PRIVATE BANKING CONSUMERS: THE ROLE OF POST-TRANSGRESSION FORGIVENESS}

\begin{abstract}
While service failure is inevitable in the banking sector, the manner in which service recovery efforts are expedited poses vital implications for organizations vested in profitable relationships with their clients. In this vein, this study investigates the significance of post-transgression forgiveness in defining the resultant satisfaction levels of customers. A structured questionnaire was self-administered among 371 premium banking customers. The findings point to the salience of selected service recovery efforts towards the forgiveness inclinations and ultimate satisfaction levels of banking customers. In particular, both bank reciprocity norms $(\beta=0.459$; $\mathrm{p}<0.000)$ and extra-role behavior $(\beta=0.348 ; \mathrm{p}<0.003)$ positively influence posttransgression forgiveness by customers. On the other hand, extra-role behavior $(\beta=0.407 ; p<0.007)$ and forgiveness $(\beta=0.373 ; p<0.008)$ positively influence bank service satisfaction. Nevertheless, bank reciprocity was found to have a positive influence on extra-role behavior $(\beta=0.548 ; \mathrm{p}<0.000)$ in this study. The findings suggest the need for the development of a prescribed set of guidelines and bank procedures to support personalized service recovery efforts in the wake of service failures
\end{abstract}

\section{Keywords}

JEL Classification service recovery, forgiveness, extra-role behavior, bank reciprocity, customer satisfaction, South Africa

\section{INTRODUCTION}

According to the Banking Association of South Africa (2010), the South African banking industry is viewed as world class, particularly after surviving the global recession between 2008 and 2010. The banking industry contributed 21.2 percent to the country's gross domestic product (GDP) between 2010 and 2013. Nevertheless, unprecedented levels of latent demand still exist among the 13 million unbanked consumers in the country (Imeson, 2010). While this is so, voracious competitive pressure has mandated a review of marketing and service delivery strategies among banking institutions, in view of stressing longlasting relationships with customers (Perrien et al., 1993). While an infinitesimal appetite still exists for banking services in the country, 2012 forecasts indicate that the potential market growth has declined to below 20 percent (Van Niekerk, 2012, p. 101). In this vein, the poten; tial differentiating factor has been to provide support services, which often is deemed the first step towards a relationship-based banking philosophy. 
Both the retail and private banks are major role players among South African financial institutions (Coetzee, Van Zyl, \& Tait, 2013, p. 4). However, the focus of this study is limited only to the private banking industry, which involves a dedicated banker, thereby stressing the need for strengthened relationships. Nevertheless, the challenges of maintaining a strong long-lasting relationship with private bankers so often presents an indelible mandate on service providers to look for ways of ensuring high service quality provision at all times. The South African banking industry provides a suitable framework in which to conduct the study, given the high levels of service failure identified by clients in that industry (Coetzee et al., 2013). Nevertheless, since private banking clients require personalized and dedicated levels of service, it remains imperative for banks to understand customer complaints and the service recovery responses they consider appropriate when a service failure, in fact, occurs.

This article is structured in the following manner: the literature is reviewed in light of service failure and the service recovery paradox (SRP). Thereafter, the author establishes the research objectives leading to hypotheses development. Next, the methodology applied in this work is discussed, prior to presenting the data analysis results and discussion. In conclusion, the article hints at the limitations of the study and further extends avenues for future research.

\section{LITERATURE REVIEW}

\subsection{Service failure within the banking industry}

According to Egan (2011, p. 14), services are an intangible phenomenon, implying that service failure is an expected end within the banking sector. Lewis and Spyrakopoulos (2001) define service failure as anything that could potentially go wrong when consuming a service. Specifically, service failures could result from the inability to meet the customer's needs and anticipations while leaving them dissatisfied (Sivakumar et al., 2014). Seemingly, the survival of banks like other service organizations is premised upon keeping existing customers happy (Petzer \& Mostert, 2012). Nevertheless, bank services typically require human interaction (Michel, 2004, p. 367). Apart from human contact, automation is possible through automated teller machines (ATMs) and Internet banking. Nonetheless, the simultaneous delivery and consumption of banking services is usually influenced by uncontrollable factors, thereby leading to inevitable service failures. This inseparability of service offerings and the very nature of intangibility give rise to service failures (Palmer, 2001, p. 74).

Siddiqui and Tripathi (2010) have identified three classes of bank service failure in the literature. First, failure emanates from inaccessible services such as an Internet banking site that is temporarily out of service. Secondly, unresponsive service delivery such as waiting too long to be served in a banking hall queue is a form of service failure. Thirdly, service failure constitutes unanticipated behavior comprising unfriendly or inappropriately behaving bank personnel. Nikbin et al. (2011) highlight the importance of service recovery efforts initiated by the company in view of remedying the initial service failure. In light of this, McCullough et al. (2000) and Smith and Bolton (1998) bring into question the implied view of a SRP in which corresponding recovery efforts by management lead to substantially higher levels of satisfaction than are produced prior to the service failure.

\subsection{Theoretical foundation: the service recovery paradox (SRP)}

This study is premised in the service recovery paradox (SRP) (McCullough \& Bharadwaj, 1992) and the subsequent response by McCullough et al. (2000) to apply forgiveness models to understand service recovery strategies. The SRP refers to situations in which a customer's postfailure satisfaction exceeds pre-failure satisfaction. Upon explaining the SRP, Smith and Bolton (1998) allude to an uncommon scenario whereby post-recovery satisfaction is greater than prior to the service failure when customers receive high recovery performance. The SRP 
postulates that heightened levels of satisfaction with a service occur after customers have experienced an effective recovery strategy (Hart et al., 1990). The SRP is akin to secondary satisfaction following an initial service failure in which customers compare their expectations for recovery to their perceptions of the actual service recovery performance. If perceptions of service recovery performance are greater than expectations (termed positive disconfirmation), a paradox might emerge whereby secondary satisfaction becomes greater than pre-failure satisfaction. On the contrary, if service recovery performance falls short of customers' expectations (negative disconfirmation), a double negative effect occurs, whereby service failure is followed by a flawed recovery (Smith \& Bolton, 1998; McCullough, Berry, \& Yadav, 2000).

\subsection{Service recovery and post- transgression forgiveness}

Service recovery seeks to "reverse customers' loss" (Fang, Luo, \& Jiang, 2013, p. 344). In explicit terms, service recovery provides an opportunity to correct the processes and circumstances that evoked the service failure in the first instance (Noth et al., 2015). In this vein, Lewis and Spyrakopoulos (2001) intimate that service recovery refers to any attempt to turn a dissatisfied customer into a happy and content one. However, Berry et al. (1990), Bolton and Drew (1991) and Fornell (1992) found contradictory results as to this paradox, discovering that lingering grievance often remains, even after superlative recovery (Buttle \& Burton, 2002). Furthermore, a recent study that aimed to clarify the SRP found that this is a valid concept, but a number of factors, primarily the context of the service encounter, including the history and length of relationships, as well as severity of service failure, moderate and mediate its operationalization (Magnini et al., 2007). Under these circumstances, forgiveness becomes a critical issue in long-term service recovery.

Grounded in Judeo-Christian tradition, forgiveness refers to the "removal of reprisal for transgressions" (Richardson, 1962 p. 49). While receiving considerable attention in the marketing literature (Beverland et al., 2010; Xie \& Peng, 2009; Tsarenko \& Tojib, 2012; Zourrig, 2015), research- ers have placed emphasis on how the forgiveness trait can be used by customers to deal with corporate wrongdoings or product failures. In other words, forgiveness is a combination of pro-social changes in a person's basic inter-personal motivations following a transgression that helps in maintaining relationships in post-transgression scenarios (McCullough et al., 2001). Although initially framed within theological contexts, the concept of forgiveness is instrumental in gaining a deep insight into consumer behavior. Consumer forgiveness, therefore, implies an intentional effort by the consumers toward overcoming posttransgression negative emotions through forgiveness for the sake of maintaining a constructive relationship with the service provider. Notably, Joireman et al. (2016, p. 77) define forgiveness as the "customers' internal act of relinquishing anger and the desire to seek revenge against a firm that has caused harm, as well as the enhancement of positive emotions and thoughts toward this harm-doing firm". In other words, forgiveness is relevant as a coping mechanism after a positive service recovery effort as deemed by the customer's strength of relationship with the company (Zourrig, 2015). In this situation, customers use forgiveness to release negative emotions and minimize any motivation to harm the service provider. Thus, forgiveness not only builds positive behavior, but also provides the basis to re-establish damaged business-customer relationships (Chung \& Beverland, 2006).

Duffy et al. (2006, p. 114) caution that service businesses should "take special care when they offer responses for service recovery". This is because all service recovery responses are not equally effective in improving customer satisfaction. Service providers should take the stance of relationship rebuilding (both explicit and implicit) after the occurrence of a service failure. Moreover, Grégoire et al. (2009, p. 29) made a call for research to "offer a more complete examination of the forgiveness construct by examining its positive constituents". This has provided direction to guide the central tenets of this paper, which pinpoint that in the case of South African private banking customers, bank reciprocity and extra-role behavior are the two superseding reparation-seeking behavior that attempt to reduce the injustice gap after a bank service failure scenario. 


\section{RESEARCH OBJECTIVES}

The following objectives were formulated:

1) primary objective:

- to examine the influence of service recovery efforts by bank personnel on the forgiveness intentions and subsequent cumulative satisfaction of private banking customers;

2) secondary objectives:

- to establish the influence of bank reciprocity on extra-role behavior;

- to investigate the predictive power of extrarole behavior and bank reciprocity on consumers' forgiveness inclinations;

- to determine the impact of extra-role behavior by banking personnel on customer satisfaction;

- to examine the influence of post-transgression forgiveness on customer satisfaction after specified service recovery efforts by bank personnel.

\section{HYPOTHESES FORMULATION}

\subsection{Bank reciprocity and extra-role behavior}

According to the reciprocity norm, individuals ought to react similarly to the way they perceive to be treated (Gouldner, 1960). Positive actions should be accredited with rewards, while negative actions receive punishment (Cropanzano \& Mitchell, 2005). Compelled by the expectancy that good will prevail in all circumstances, the reciprocity norm helps to quell undesirable emotions, thus serving as a "shock absorber" to provide relief to the harmed party (Bagozzi, 1995, p. 276). Therefore, upholding a norm of reciprocity may generate an inclination to make up for the loss incurred during the service failure. In response, banking companies seek to repair the loss of ser- vice failure by proffering a monetary reward to customers (Smith et al., 1999). In the current scenario, the bank offers a bank-charge free transaction to premium customers at their next encounter. Expressed in this manner, reciprocity is as a norm that is driven by organizational indebtedness to its clients (Gouldner, 1960). This implies that reciprocity could drive customers' to perceive bank employees as performing extra-role behavior to stabilize the exchange relationship. It is thus hypothesized that:

H1: Bank reciprocity following service recovery efforts positively influences extra-role behavior by bank personnel.

\subsection{Bank reciprocity and forgiveness}

After reciprocal reactions, the customer's disappointment derived from the service failure is reduced and the customer feels better. The resulting reactions are considered a catalyst to reduce the tension between the customer and the firm. Although the customer's feeling about the firm is not as positive as before the occurrence of the mistake, the actions (avoiding the firm or taking revenge against the firm) performed to reduce the tension would help the customers regain balance. In assessing this reward, customers are likely to rely on the reciprocity norm to resist evil and make reparation for any harm caused. In this vein, customers observe the firm's reciprocal response and feelings of forgiveness are generated. Therefore:

H2: Bank reciprocity following service recovery efforts positively influences customers' forgiveness intentions.

\subsection{Extra-role behavior and forgiveness}

During a service recovery scenario, banking personnel needs to project the best efforts to go beyond explicit role requirements. While not directly or indirectly recognized by the formal rewards system, extra-role behavior is likely to be internally motivated, arising out of an em- 
ployee's need for accomplishment. The interest in organisation-citizenship behavior relates to extra-role behavior that private banking personnel service employees might adopt. This might comprise improving the quality of service delivery or behaving in a conscientious manner. Of note, after a service failure, is that the 'good soldier syndrome' is evident where employees perform extra-role behavior and this could positively impact the customers' willingness to forgive the bank. Therefore:

H2a: Extra-role behavior by bank personnel following service recovery efforts positively influences customers' forgiveness intentions.

\subsection{Extra-role behavior and bank service satisfaction}

Private banking involves a high level of intimate interactions; therefore, customer-employee rapport is an imperative to build customer satisfaction, loyalty and positive word of mouth (Gremler \& Gwinner, 2000). When employees adopt customer-oriented behavior, customers rate the quality of service interactions higher (Rafaeli et al., 2008; Wang, 2010). Further, corporate citizenship behavior on the job enhances customer trust and value, which positively influence customer loyalty intentions (Briggs \& Grisaffe, 2010). Therefore, it is expected that extra-role behavior will influence the service satisfaction of private banking customers as hypothesized below:

H3: Extra-role behavior following service recovery efforts positively influences service satisfaction.

\subsection{Customer forgiveness and bank service satisfaction}

According to Aaker et al. (2004), most researchers have overlooked the positive emotion of coping behavior such as the empathy of forgiveness that can be the bridge to customer satisfaction and lead the customer to rehabilitate the relationship. When the negative motivation decreases, customers will be more open-minded to increase positive motivation to restore their relationship with the company. Therefore, forgiveness can play a role as a coping strategy for negative behavior owing to poor or bad service (Tsarenko \& Tojib, 2011; Zourrig et al., 2009; Moschis, 2007). Moreover, forgiveness that comes after noting the company's efforts at service recovery can contribute towards positive action through word of mouth (Howley et al,. 2008). Therefore, it is hypothesized that:

\section{H3a: Customers' forgiveness intentions following service recovery efforts positively influence service satisfaction.}

The following methodology was applied in lieu of concluding the stated hypotheses.

\section{RESEARCH DESIGN AND METHODS}

A positivist research philosophy was followed in this research, wherein a descriptive research strategy was followed using a mono-quantitative research approach.

\subsection{Sampling and participants}

Internet services breakdown is a regular phenomenon in South Africa and private banking customers are among the most affected segments owing to their high affinity for convenient banking opportunities thereby proffering an ideal population to carry out this survey. The target population comprised private banking clients of the four major banks located in the Western Cape and Gauteng provinces of South Africa. A non-probability sampling technique in the form of snowball sampling was used to select research participants on a referral basis starting with the researcher's immediate acquaintances. The questionnaire contained a hypothetical service failure incident (Appendix A) and participants were asked to provide their response while assuming themselves in the same situation. For practical and ethical advantages, a real service failure situation within a banking context was used to eliminate elements re-collection bias (Smith et al., 1999, p. 362). Moreover, the target population admitted to having experienced an Internet downtime error in their banking service encounters. 


\subsection{Measures and data collection}

The researcher was involved personally in the data collection process, by screening the prospective respondents for eligibility and to request the respondents to complete the questionnaire. Data were collected by means of a self-administered, structured questionnaire. Initially, the demographic and banking profile of the participants was sought. Thereafter, adapted measures were presented relating to a specified service failure scenario. Five items measuring extra-role behavior (ERB1-ERB5) and four items measuring service satisfaction after the service recovery efforts (BSS1-BSS4) were adapted from Maxham and Netemeyer (2003). Consumer forgiveness (FG1-FG5) was measured by the scale used by McCullough et al. (2000), while bank reciprocity scale items (BR1-BR6) were adapted from a study by Arnett, German, and Hunt (2003). In concert with empirical precedence, the scales used in this research were anchored on a sevenpoint Likert scale. A scale based on seven points was considered ideal, because it enables the measurement of direction and neutrality while distinguishing three levels of intensity. In essence, this leads to the communication of vast information.

\subsection{Sample composition}

Of the 371 respondents, 229 (61.7\%) were reported to be male, while 142 were female (38.3\%). In terms of education, 41.3 percent $(n=153)$ indicated a university degree (Bachelor's degree) as their highest level of education, followed by postgraduate degree studies ( $\mathrm{n}=107 ; 28.8 \%)$. The largest representation in terms of age group was the 40 to 49 age bracket $(\mathrm{n}=201 ; 54.3 \%)$, followed by those between the 30 to 39 year age range $(n=111 ; 29.8 \%)$. Those aged 50 years or older ( $\mathrm{n}=20 ; 5.4 \%), 20$ to 29 years $(\mathrm{n}=34 ; 9.2 \%)$ and 20 years or younger $(\mathrm{n}=5 ; 1.4 \%)$ were the minority groups represented in this study. The most popular bank patronage was leaning towards Investec bank $(\mathrm{n}=124 ; 33.4 \%)$, Standard Bank $(\mathrm{n}=79 ; 21.3 \%)$ and Nedbank $(\mathrm{n}=57$; $15.4 \%$ ) in that order. The sample comprised only private-banking customers, purporting to be priority bankers in the top-tier level of either black card $(\mathrm{n}=139 ; 37.5 \%)$ or platinum card $(\mathrm{n}=98$; 26.4\%) holders within the respective banks. In ad- dition, the customers alluded to have been with their respective banks for more than five years $(\mathrm{n}=183 ; 49.3 \%)$, or at least between three and five years $(\mathrm{n}=102 ; 27.5 \%)$, with particular bearing on a strong business to customer relationship.

\section{DATA ANALYSIS}

Exploratory factor analysis (EFA) was conducted on SPSS (version 24.0) as the primary procedure for scale purification, whereas PLS path modelling analysis was employed in hypotheses testing. A two-pronged procedure was applied in the model assessment, commencing with an evaluation of the outer model, followed by an assessment of the reliability and validity of the model. Thereafter, the inner model was evaluated leading to the interpretation of the results.

\subsection{Exploratory factor analysis (EFA) procedure}

Initially, the principal components extraction method was applied with Varimax rotation to determine the underlying factor structure and dimensionality. Consistent with Hair et al. (2011), three criteria were checked for retaining items in this study: (1) loadings of more than 0.50 on a factor; (2) items not loading above 0.50 on separate factor, and (3) items with communality values of 0.50 and greater with item-to-total correlation values greater than 0.40. Items FG5, ERB4, ERB5 and item BR5 were deleted as they failed to meet the required thresholds. Moreover, the identified factors loaded with mean values greater than 3.5 , indicating a high degree of agreeableness among the consumers regarding bank service satisfaction.

\subsection{Outer model evaluation}

A SEM procedure following SmartPLS (3.0) was applied on the data set. SmartPLS has the great advantage over other covariance-based methods (CBM), because it requires fewer data points (small sample size) to accurately estimate loadings, while the procedure is not sensitive to data normality violation. The outer and inner model results are presented consecutively as follows: 
Table 1. Outer model results

\begin{tabular}{|c|c|c|c|c|c|c|c|c|c|}
\hline \multirow[b]{2}{*}{ Construct } & \multirow[b]{2}{*}{$\stackrel{\Xi}{巳}$} & \multirow[b]{2}{*}{ 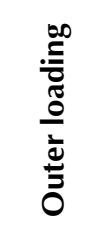 } & \multicolumn{2}{|c|}{ Collinearity tests } & \multicolumn{3}{|c|}{ Reliability tests } & \multicolumn{2}{|c|}{ Validity tests } \\
\hline & & & $\frac{\mathscr{d}}{\frac{D}{N}}$ & 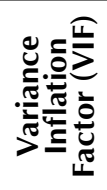 & 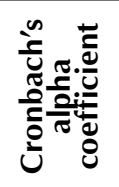 & 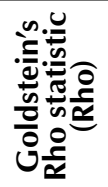 & 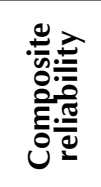 & 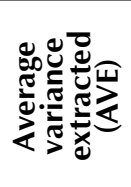 & $\stackrel{\rightleftarrows}{\lessgtr}$ \\
\hline \multirow{5}{*}{$\begin{array}{l}\text { Bank } \\
\text { reciprocity }\end{array}$} & BR1 & 0.854 & 25.098 & 2.325 & \multirow{5}{*}{0.856} & \multirow{5}{*}{0.889} & \multirow{5}{*}{0.895} & \multirow{5}{*}{0.632} & \multirow{5}{*}{0.795} \\
\hline & BR2 & 0.857 & 28.675 & 2.531 & & & & & \\
\hline & BR3 & 0.830 & 13.371 & 2.212 & & & & & \\
\hline & BR4 & 0.713 & 8.714 & 1.908 & & & & & \\
\hline & BR6 & 0.709 & 8.009 & 1.803 & & & & & \\
\hline \multirow{3}{*}{$\begin{array}{l}\text { Extra-role } \\
\text { behavior }\end{array}$} & ERB1 & 0.829 & 16.754 & 1.882 & \multirow{3}{*}{0.717} & \multirow{3}{*}{0.722} & \multirow{3}{*}{0.839} & \multirow{3}{*}{0.634} & \multirow{3}{*}{0.797} \\
\hline & ERB2 & 0.791 & 11.973 & 1.831 & & & & & \\
\hline & ERB3 & 0.769 & 17.943 & 1.179 & & & & & \\
\hline \multirow{4}{*}{ Forgiveness } & FG1 & 0.817 & 18.547 & 1.600 & \multirow{4}{*}{0.753} & \multirow{4}{*}{0.761} & \multirow{4}{*}{0.843} & \multirow{4}{*}{0.574} & \multirow{4}{*}{0.758} \\
\hline & $\mathrm{FG} 2$ & 0.745 & 11.318 & 1.472 & & & & & \\
\hline & FG3 & 0.758 & 12.029 & 1.405 & & & & & \\
\hline & FG4 & 0.707 & 8.618 & 1.329 & & & & & \\
\hline \multirow{4}{*}{$\begin{array}{l}\text { Bank service } \\
\text { satisfaction }\end{array}$} & BSS1 & 0.867 & 28.450 & 2.351 & \multirow{4}{*}{0.776} & \multirow{4}{*}{0.783} & \multirow{4}{*}{0.858} & \multirow{4}{*}{0.603} & \multirow{4}{*}{0.777} \\
\hline & BSS2 & 0.661 & 8.379 & 1.231 & & & & & \\
\hline & BSS3 & 0.797 & 16.491 & 1.937 & & & & & \\
\hline & BSS4 & 0.767 & 16.664 & 1.533 & & & & & \\
\hline \multicolumn{2}{|c|}{ Recommended threshold } & $\geq 0.70$ & $\geq 1.96$ & $\leq 5.00$ & $\geq 0.70$ & $\geq 0.70$ & $\geq 0.70$ & $\geq 0.50$ & $\begin{array}{l}\text { >largest }(r) \\
\text { correlation }\end{array}$ \\
\hline
\end{tabular}

While data normality is not a necessary pre-requisite to run a SEM procedure on SmartPLS, the conventional procedure is to check if there are any potential collinearity problems in the data set as this has a bearing on the theoretical uniqueness of each construct used in the study. In light of this, t-statistics, as well as variance inflation factor (VIF) values were computed on the indicator variables. There were no collinearity problems in this study, since the t-values, ranging between 8.009 and 28.675 (greater than 1.96), as well as the VIF values ranging between 1.179 and 2.531 (below 5.0) were within the acceptable thresholds recommended by Wong (2013).

The indicator variables were subjected to reliability testing using a triple set of statistics. Cronbach's alpha coefficient values ranged between 0.717 and 0.856 , while the computed Rho values ranged between 0.722 and 0.889 . On the other hand, composite reliability values ranged between 0.839 and 0.895 . The results in Table 1 show that all the constructs of interest in this study were highly reliable in concert with Hair et al. (2011) who pointed out that values of 0.7 and higher across all three statistics are indicative of internal consistency of a research.

The outer loadings and AVE values were assessed in view of determining the convergent validity of this work. In particular, the outer loadings for bank reciprocity (0.709 to 0.857$)$, extra-role behavior ( 0.769 to 0.829 ), forgiveness ( 0.707 to 0.817 ) and bank service satisfaction (0.661 to 0.867 ) were above 0.70 , while the bootstrapping procedure reported large $t$-statistics $(t \geq 1.96)$ suggesting statistically significant factor loadings. Of note, item BSS2 reported an outer loading value of 0.661 (slightly below 0.70 ). While Hair et al. (2013) point out that composite reliability of a study can be improved by eliminating all items that load poorly (between 0.40 and 0.70); an expert assessment highlighted the importance of item BSS2 (I feel very satisfied with my decision to use the services of this bank) for the overall conceptualisation of the main endogenous construct. Therefore, a decision was made to retain the observed variable BSS2. Furthermore, the reported AVE values were 
Table 2. Pearson correlation analysis results and descriptive measures

\begin{tabular}{l|c|c|c|c}
\hline \multicolumn{1}{c}{ Construct } & Bank reciprocity & $\begin{array}{c}\text { Extra-role } \\
\text { behavior }\end{array}$ & Forgiveness & $\begin{array}{c}\text { Bank service } \\
\text { satisfaction }\end{array}$ \\
\hline Bank reciprocity & 1 & & & \\
Extra-role behavior & $0.448^{* *}$ & 1 & & \\
\hline Forgiveness & $0.550^{* *}$ & $0.500^{* *}$ & 1 & 1 \\
\hline Bank service satisfaction & $0.503^{* *}$ & $0.530^{* *}$ & $0.517^{* *}$ & 1 \\
Mean & 3.770 & 3.537 & 3.528 & 3.644 \\
\hline Standard deviation & 1.269 & 0.947 & 0.972 & 1.071 \\
\hline
\end{tabular}

Note: ${ }^{\star \star} \mathrm{r}$ is significant at $\mathrm{p}=0.01$.

in the following order: forgiveness (AVE $=0.574$ ), bank service satisfaction (AVE $=0.603$ ), bank reciprocity (AVE=0.632) and extra-role behavior (AVE $=0.634)$. These results in Table 1 demonstrate that more than 50 percent of the observed variables correlate well within their parent factor, in this manner explaining the latent variable soundly.

Discriminant validity was assessed using three statistics. First, none of the correlation coefficient values between two related constructs in Table 2 were exactly 1.00 ( \pm 2 standard errors), indicating the theoretical uniqueness of the measures used in this study, consistent with the extrapolation by Anderson and Gerbing (1988). Secondly, Fornell and Larcker's (1981, p. 46) criterion whereby an observation was made whether the correlation estimates are lower than all the computed square-roots of AVE values in this study.
Notably, the correlation coefficient values in the matrix were all significant ( $p=0.01$ ), ranging between 0.448 and 0.550 , which is below the lowest square root of the computed AVE values on Table 1 (0.758). Thirdly, the hetero-mono-trait (HTMT) ratio proposed by Henseler et al. (2015) were reported to be within the acceptable zone, ranging between 0.615 and 0.840 (below 0.85 ) across all the constructs used in this work.

\subsection{Inner model evaluation}

The path weighting scheme was used to run a sequence of regressions (300 iterations) on Smart PLS in terms of weight vectors in view of providing the highest coefficient of determination $\left(\mathrm{R}^{2}\right)$ value on each endogenous variable. In addition, hypotheses were either accepted or rejected after

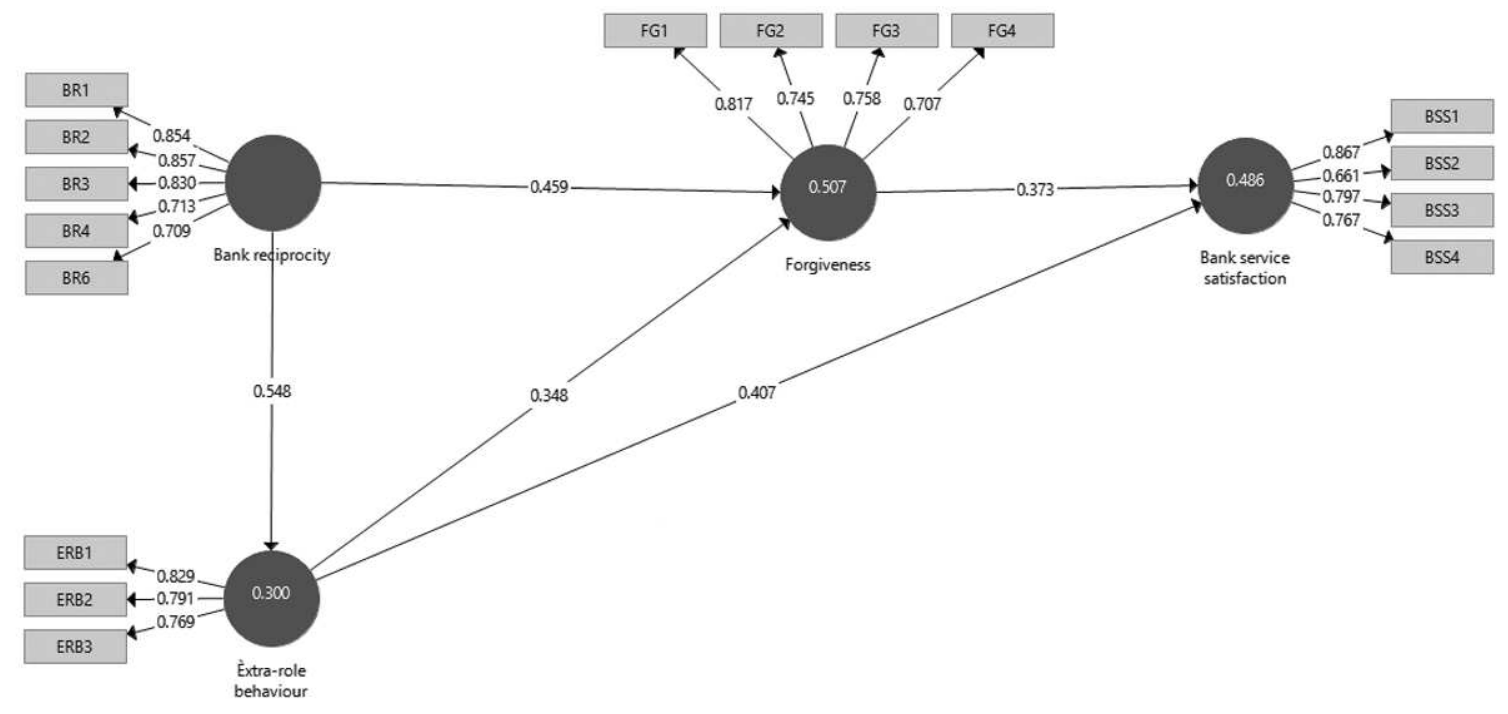

Figure 1. Inner model results 
Table 3. Inner model results

\begin{tabular}{|c|c|c|c|c|c|c|}
\hline Causal path & $\begin{array}{c}\text { Path } \\
\text { estimate }\end{array}$ & $\mathbf{R 2}$ & t-value & p-value & VIF (Inner) & Decision \\
\hline $\mathrm{H} 1=$ Extra-role behavior $\longleftarrow$ Bank reciprocity & 0.548 & 0.300 & 6.882 & 0.000 & 1.000 & Supported \\
\hline $\mathrm{H} 2=$ Forgiveness $\longleftarrow$ Extra-role behavior & 0.348 & \multirow{2}{*}{0.507} & 3.663 & 0.003 & 1.429 & Supported \\
\hline $\mathrm{H} 2 \mathrm{a}=$ Forgiveness $\longleftarrow$ Bank reciprocity & 0.459 & & 4.846 & 0.000 & 1.429 & Supported \\
\hline $\mathrm{H} 3=$ Bank service satisfaction $\longleftarrow$ Forgiveness & 0.373 & \multirow{2}{*}{0.486} & 3.818 & 0.007 & 1.562 & Supported \\
\hline $\mathrm{H} 3 \mathrm{a}=$ Bank service satisfaction $\longleftarrow$ Extra-role behavior & 0.407 & & 4.192 & 0.008 & 1.562 & Supported \\
\hline
\end{tabular}

observing the large significance levels $(p<0.01$; $99 \%$ CI) inferring high levels of accuracy. Figure 1 presents the inner model results.

The path coefficients and the coefficients' significant $(p)$ values were used in hypotheses testing. The size and relevance of each path was computed by running the path algorithm. In particular, Chin $(1998, p .13)$ suggests that only standardized path coefficient values greater than \pm 0.20 should be considered noteworthy of reporting in SEM studies. Table 3 presents a summary of the statistics used in determining the significance testing results of the inner model.

\subsection{Hypotheses testing results}

Table 3 tabulates the complete findings to justify correctness of the structural model that was tested in this research. In terms of the independent path between extra-role behavior and bank reciprocity, the results show a positive and significant influence $(\beta=+0.548 ; t=6.882 ; p=0.000)$. In this vein, the first hypothesis $(\mathrm{H} 1)$ was supported in this research. In the same breath, an examination of the coefficient of determination $\left(\mathrm{R}^{2}\right)$ was made proving how much of the exogenous variables have a combined effect on the endogenous variable. Therefore, in lieu of estimating the predictive accuracy of this work, a "rough" rule suggested by Hair et al. (2013, p. 113) was followed stating that $\mathrm{R}^{2}$ values of 0.75 to one (substantial power), 0.50 to 0.749 (moderate power) and 0.25 to 0.499 (weak power) are worthy of reporting. Therefore, it may be inferred that extra-role behavior posed weak $\left(\mathrm{R}^{2}=0.300\right)$ predictive power on bank reciprocity.

Both extra-role behavior $(\beta=+0.348 ; t=3.663$; $p=0.003)$ and bank reciprocity $(\beta=+0.459 ; t=4.846$; $p=0.000$ ) were found to have a positive and significant influence on customers' inclinations towards forgiving bank service providers. Based on these results, hypotheses $2(\mathrm{H} 2)$ and $(\mathrm{H} 2 \mathrm{a})$ are hereby accepted. Scrutiny of the coefficient of determination $\left(\mathrm{R}^{2}\right)$ suggests that extra-role behavior and bank reciprocity had substantial predictive power in the model reported at 51 percent $\left(\mathrm{R}^{2}=0.507\right)$.

Forgiveness showed a significant and positive influence on customer satisfaction with bank services $(\beta=+0.407 ; t=4.192 ; p=0.007)$. This was consistent with hypothesis $3(\mathrm{H} 3)$. On the other hand, a positive influence was established between extra-role behavior $(\beta=0.373+; t=3.818 ; p=0.008)$ and customer satisfaction with banking services post the service failure encounter. Thus, hypothesis $\mathrm{H} 3 \mathrm{a}$ was also supported in this work. Moreover, forgiveness and extra-role behavior reported near moderate predictive accuracy on bank service satisfaction $\left(R^{2}=0.486\right)$. Since all hypotheses were accepted, this indicates that both extra-role behavior and bank reciprocity are significant determinants of post-transgression forgiveness, while extra-role behavior and forgiveness predict customer satisfaction with banking services among the private banking consumers.

\section{CONCLUSION}

Hart et al. (1990, p. 49) state that employees' ability to discover and resolve service failures to the customers' satisfaction is "a chance to go beyond the call of duty and win a customer for life". This study specifically looked at the momentous role of post-transgression forgiveness, prompted by bank reciprocity and extra-role behavior of banking personnel. In addition, a positive influence was extrapo- 
lated between extra-role behavior and forgiveness on customer satisfaction with the bank services. The results of the study are a movement towards understanding how recovery efforts can enhance the satisfaction levels of South African private banking consumers. The findings concur with previous studies pinpointing that a strong service recovery initiative is highly correlated with both customer satisfaction and the customer's propensity to spread positive word-of-mouth about the service provider (Tsarenko \& Tojib, 2011; McCullough et al., 2000; Berry, 1995).

\section{FUTURE DIRECTIONS FOR RESEARCH}

This work signals the direct course of action to be taken by bank service personnel during service recovery efforts. Although the constructs used in the research model have proved to be informative, the study focused only on a single failure encounter, which may be restrictive, in part, owing to the transitory nature of bank service relationships implying that multiple service failures will be experienced. Nevertheless, it is yet to be seen how a deliberate act of forgiveness can serve as a baseline to assist customers to respond to multiple failures positively. In this vein, longitudinal research could be conducted to investigate the dynamics of forgiveness as a unidimensional construct. Relatedly, since double deviations are likely to generate anger, customer forgiveness becomes relevant leading to the need for concurrent studies to proceed on an understanding of both episodic and trait forgiveness. Such investigations would help to clarify the cumulative processes that complainants experience after pardoning their respective bank service providers. Lastly, this study was conducted in South Africa. Therefore, it is difficult to generalize the findings across different cultural and economic contexts. Notably, the South African banking environment presents its own unique challenges that might differ from those of other countries.

\section{REFERENCES}

1. Aaker, J., Fournier, S., \& Brasel, A. S. (2004). When good brands do bad. Journal of Consumer Research, 31(1), 1-16.

2. Anderson, J. C., \& Gerbing, D. W. (1988). Structural equation modelling in practice: A review and recommended two-step approach, Psychological Bulletin, 103, 411-423.

3. Arnett, D. B., German, S. D., \& Hunt, S. D. (2003). The identity salience model of relationship marketing success: The case of non-profit marketing. Journal of Marketing, 67(2), 89-105.

4. Bagozzi, R. P. (1995). Reflections on relationship marketing in consumer markets. Journal of Academy of Marketing Science, 23, 272.

5. Banking Association of South Africa (2012). South African banking industry overview. Retrieved August 20, 2017 from http://www.banking.org.za/index. php/our-industry/2012-southafrican-banking-sector-overview

6. Berry, L. L. (1995). Relationship marketing of services- growing interest, emerging perspectives. Journal of the Academy of Marketing Science, 23(4), 236-245.

7. Berry, L. L., Zeithaml, V. A., \& Parasuraman, A. (1990). Five imperatives for improving service quality. Sloan Management Review, 31(4), 29-38.

8. Beverland, M. B., Kates, S. M., Lindgreen, A., \& Chung, E. (2010). Exploring consumer conflict management in service encounters. Journal of the Academy of Marketing Science, 83, 617-633.

9. Bolton, R. N., \& Drew, J. H. (1991). A multistage model of customers' assessments of service quality and value. Journal of Consumer Research, 17(4), 375-384.
10. Briggs, E., \& Grisaffe, D. (2010). Service performance-loyalty intentions link in a B2B context: The role of relational exchange outcomes and customer characteristics. Journal of Service Research, 13(1), 37-51.

11. Buttle, F., \& Burton, J. (2002). Does service failure influence customer loyalty? Journal of Consumer Behavior, 1(3), 217-227.

12. Chin, W. W. (1998). The partial least squares approach to structural equation modelling. In Marcoulides, G.A. (Ed.), Modern methods for business research (pp. 295-336). Lawrence Erlbaum Associates, Mahwah, NJ.

13. Chung, E., \& Beverland, M. (2006). An exploration of consumer forgiveness following marketer transgression. Advance in Consumer Research, 33, 98-99.

14. Coetzee, J., Van Zyl, H., \& Tait, M. (2013). Perceptions of service quality by clients 
and contact-personnel in the South African retail-banking sector. Southern African Business Review, 17(1), 1-22. Retrieved from https://www.researchgate. net/publication/310254960_ Perceptions_of_service_quality_ by_clients_and_contactpersonnel_in_the_South_African_ retail_banking_sector

15. Cropanzano, R., \& Mitchell, M. S. (2005). Social exchange theory: An interdisciplinary review. Journal of Management, 6, 874-900.

16. Duffy, J. A. M., Miller, J. M., \& Bexley, J. B. (2006). Banking customers' varied reactions to service recovery strategies. International Journal of Bank Marketing, 24(2), 112-132.

17. Egan, J. (2011). Relationship marketing: Exploring relational strategies in marketing ( $4^{\text {th }} \mathrm{ed}$.). Harlow: Prentice Hall.

18. Fang, Z., Luo, X., \& Jiang, M. (2013). Quantifying the dynamic effects of service recovery on customer satisfaction: Evidence from Chinese mobile phone markets. Journal of Service Research, 16(3), 341-355.

Retrieved from http://citeseerx.ist. psu.edu/viewdoc/download?doi $=10.1 .1 .822 .9586 \& \mathrm{rep}=\mathrm{rep} 1 \&$ typ $\mathrm{e}=\mathrm{pdf}$

19. Fornell, C. (1992). A national customer satisfaction barometer: The Swedish experience. Journal of Marketing, 56, 6-21.

20. Fornell, C., \& Larcker, D. F. (1981). Evaluating structural equation models with unobservable variables and measurement errors. Journal of Marketing Research, 18(February), 39-50.

21. Gouldner, A. W. (1960). The norm of reciprocity: A preliminary statement, American Sociological Review, 25(2), 61-178.

22. Grégoire, Y., Tripp, T. M., \& Legoux, R. (2009). When customer love turns into lasting hate: The effects of relationship strength and time on customer revenge and avoidance. Journal of Marketing, 73(6), 18-32.

23. Gremler, D. D., \& Gwinner, K. P. (2000). Customer-employee rapport in service relationships. Journal of Services Research, 3, 82-104.

24. Hair, J. F. (Jr)., Black, W. C., Babin, B. J., \& Anderson, R. E. (2010). Multivariate data analysis ( $7^{\text {th }} \mathrm{ed}$.). New York, USA: Prentice-Hall.

25. Hair, J. F., Wolfinbarger Celsi, M., Oritinau, D. J., \& Bush, R. P. (2013). Essentials of marketing research ( $3^{\text {rd }}$ international ed.). New York: McGraw Hill. Retrieved from https://www.amazon.com/Essentials-MarketingResearch-Irwin/dp/0078028817

26. Hart, C. W. L., Heskett, J. L., \& Sasser, W. E. Jr. (1990). The profitable art of service recovery. Harvard Business Review, 68(July/ August), 148-157.

27. Henseler, J., Ringle, C. M., \& Sarstedt, M. (2015). A new criterion for assessing discriminant validity in variancebased structural equation modelling. Journal of the Academy of Marketing Science, 43(1), 115135 .

28. Howley, M. J., Ward, J. C., \& Brown, S. W. (2008). The forgiveness processes of very dissatisfied customers. Retrieved August 20, 2017 from http://ssrn. com/abstract $=1153972$

29. Imeson, M. (2010). Eyes on the prize. Retrieved March 20, 2018 from http://www.thebanker.com

30. Joireman, J. Grégoire, Y., \& Tripp, T. M. (2016). Customer forgiveness following service failures. Current Opinion in Psychology, 10(1), 76-82.

31. Lewis, B. R., \& Spyrakopoulos, S. (2001). Service failures and recovery in retail banking: The customers' perspective. International Journal of Bank Marketing, 19(1), 37-47.

32. Magnini, V., Ford, J., Markowski, E., \& Honeycutt, E. (2007). The service recovery paradox: Justifiable theory or smoldering myth? Journal of Services Marketing, 21(3), 213-25.

33. Maxham, J. G. I., \& Netemeyer, R. G. (2002). A longitudinal study of complaining customers' evaluations of multiple service failures and recovery efforts. Journal of Marketing, 66(4), 57-71.

34. McCullough, M. A., Berry, L. L. \& Yadav, M. S. (2000). An empirical investigation of customer satisfaction after service failure and recovery. Journal of Service Research, 3(2), 121-137.

35. McCullough, M. E., Fincham, F. D., \& Tsang, J. A. (2003). Forgiveness, forbearance and time: The temporal unfolding of transgression-related interpersonal motivations. Journal of Personality and Social Psychology, 84(3), 540-557.

36. McCullough, M., \& Bharadwaj, S. (1992). The recovery paradox: an examination of customer satisfaction in relation to disconfirmation, service quality, and attribution based theories. In Allen, C. (Ed.), Marketing Theory and Applications, American Marketing Association, Chicago, IL.

37. McCullough, M. E., Worthington, E. L. Jr., \& Rachal, K. C. (1997), Interpersonal forgiving in close relationships. Journal of Personal Social Psychology, 73, 21-336

38. Michel, S. (2004). Consequences of perceived acceptability of a bank's service failures. Journal of Financial Services Marketing, 8(4), 367-377.

39. Moschis, G. P. (2007). Stress and consumer behavior. Journal of the Academy of Marketing Science, 35(3), 430-444

40. Nikbin, D., Ismail, I., Marimuthu, M., \& Abu-Jarad, I. Y. (2011). The impact of firm reputation on customers' responses to service failure: The role of failure attributions. Business Strategy Series, 12(1), 19-29.

41. Noth, A. C., Jaroenwanit, P., \& Brown, R. (2015). The roles of forgiveness towards repurchase intentions from a cross-cultural perspective. Athens: ATINER'S Conference Paper Series, No: MKT2014-1364. Retrieved from http://www.athensjournals.gr/ business/2015-1-3-4-Noth.pdf 
42. Palmer, A. (2001). Principles of services marketing ( $3^{\text {rd }}$ ed.). Singapore: McGraw-Hill.

43. Perrien, J., Filiatrault, P., \& Ricard, L. (1993). The implementation of relationship marketing in commercial banking. Industrial Marketing Management, 22, 141 148.

44. Petzer, D. J., \& Mostert, P. G. (2012). Attitude towards and likelihood of complaining in the banking, domestic airline and restaurant industries. Southern African Business Review, 16(2), 1-23. Retrieved from https://www. ajol.info/index.php/sabr/article/ viewFile/85459/75390

45. Rafaeli, A., Ziklik, L., \& Doucet, L. (2008). The impact of call center employees' customer orientation behavior on customer satisfaction. Journal of Services Research, 10, 239-255.

46. Richardson, A. (1962). A theological wordbook of the bible. Michigan: MacMillan Publishing Company.

47. Siddiqui, M. H., \& Tripathi, S. N. (2010). An analytical study of complaining attitudes: With reference to the banking sector. Journal of Targeting, Measurement and Analysis for Marketing, 18(2), 119-137.
48. Sivakumar, K., Li, M., \& Dong, B. (2014). Service quality: The impact of frequency, timing, proximity and sequence of failures and delights. Journal of Marketing, 78(1), 41-58.

49. Smith, A. K., \& Bolton, R. N. (1998). An experimental investigation of customer reactions to service failure and recovery encounters: Paradox or peril? Journal of Service Research, 1(1), 65-81.

50. Smith, A. K., Bolton, R. U. \& Wagner, J. (1999). A model of customer satisfaction with service encounters involving failure and recovery. Journal of Market Research, 36, 356-372.

51. Tsarenko, Y., \& Tojib, D. R. (2011). A transactional model of forgiveness in the service failure context: A customer-driven approach. Journal of Services Marketing, 25(5), 381-392.

52. Tsarenko, Y., \& Tojib, D. (2012). The role of personality characteristics and service failure severity in consumer forgiveness and service outcomes. Journal of Marketing Management, 28(9/10), 1217-1239.

53. Van Niekerk, L. (2012). South Africa yearbook 2011/12 -
Communications. Retrieved May 28, 2017 from http://www.gcis. gov.za/sites/www.gcis.gov.za/ files/docs/resourcecentre/yearbook2011/10_Communications. pdf

54. Wong, K. K-K. (2013). Partial least squares structural equation (PLSSEM) techniques using SmartPLS Marketing Bulletin, 24, Technical Note 1, 1-32.

55. Xie, Y., \& Peng, S. (2009). How to repair customer trust after negative publicity: The roles of competence, integrity, benevolence and forgiveness. Psychology Marketing, 26(7), 572589.

56. Zourrig, H., Chebat, J-C., \& Toffoli, R. (2009). Consumer revenge behavior: A cross-cultural perspective. Journal of Business Research, 62(10), 995-1001.

57. Zourrig, H., Chebat, J-C., \& Toffoli, R. (2015). In-group love and out-group hate? A crosscultural study on customers revenge, avoidance and forgiveness behavior. Journal of Business Research, 68(3), 487499. Retrieved from https://ideas. repec.org/a/eee/jbrese/v68y2015i3p487-499.html 


\section{APPENDIX A}

\section{BANK SERVICE FAILURE SCENARIO A-1}

\section{The service failure scenario reads as follows:}

After signing a contract as a private banker with your bank with access to a plethora of online banking features, you receive a message on the bank's website stating the following:

"Our card swiping and Internet banking functions were affected for short periods during Saturday (less than an hour in total) and our branch network and remote channels were affected for longer periods during the day, which obviously has had a disruptive impact on our clients who needed to make remote payments".

\section{Service recovery efforts by the bank:}

Their bank staff members make efforts to contact you, the client, on your mobile phone and tell you politely that they are sorry for your unhappy experience and explain that they are currently experiencing challenges owing to a server upgrade at their premises. They acknowledge that it is their fault that they did not communicate the possibility of a technical fault in advance and make concerted efforts to assist you, the client, to complete your transaction with ease telephonically without much inconvenience so that the effects of the downtime failure are not exacerbated. In addition, the bank offers to remove the transaction charge for your next transaction. 